\title{
EVALUATION OF ONLINE LEARNING PROGRAMS AT UNIVERSITIES USING THE CIPP MODEL
}

\author{
Eka Damayanti*
}

Islamic State University of Alauddin Makassar, Indonesia E-mail:eka.damayanti@uin-alauddin.ac.id

Misykat Malik Ibrahim

Islamic State University of Alauddin Makassar, Indonesia E-mail:misykat.mmi@gmail.com

Muh. Ilyas Ismail

\author{
Islamic State University of Alauddin Makassar, Indonesia
E-mail : ilyas.ismail@uin-alauddin.co.id \\ Islamic State University of Alauddin Makassar, Indonesia
E-mail : ilyas.ismail@uin-alauddin.co.id \\ of the Creative Commons Attribution (CC-BY-SA) license (https://creativecommons.org/licenses/by-sa/4.0/) \\ doIOI: http://dx.doi.org/10.30983/educative.v6i1.4678 \\ * Corresponding author

\begin{tabular}{|l|l|l} 
Submission : tanggal, bulan, tabun & Revised : tanggal, bulan, tahun & Published :tanggal bulan tabun
\end{tabular}

\section{Abstract}

\begin{abstract}
Online learning during the COVID-19 pandemic had both positive and negative effects, including online learning for the Dirasah Islamiyah study program, concentration on Education and Teacher Training, Postgraduate at Islamic State University of Alauddin Makassar, so it is necessary to be evaluated. The purpose of this study is to evaluate online learning programs using the Context, Input, Process, and Product (CIPP) program evaluation model formulated by Stufflebeam. This descriptive quantitative research used primary data collected from questionnaires from lecturers and students in the Learning Program Evaluation course as a source of informants and secondary data were taken using documentation in the form of Semester Learning Plans, lecture materials, and coursework results. The collected data were analyzed using descriptive statistical analysis. The results showed that the implementation of online learning at the Postgraduate Alauddin State Islamic University in Makassar, the Dirasah Islamiyah Study Program with the concentration of Education and Teacher Training had been going well although some parts still needed to be improved such as maximizing the use of the Learning Management System (LMS), clear coordination between fellow lecturers who support courses related to RPS which will be applied for one semester and strict conditioning so that students do their assignments responsibly (free of plagiarism).
\end{abstract}

Keywords: program evaluation, online learning, Context Input Process and Product (CIPP)

\section{Abstrak}

Pembelajaran daring yang berlangsung selama pandemi covid-19 menimbulkan dampak positif dan juga negative, tidak terkecuali pada pembelajaran daring program studi Dirasab Islamiyab konsentrasi Pendidikan dan Keguruan, Pascasarjana Universitas Islam Negeri Alauddin Makassar sehingga perlunya dilakukan evaluasi terhadap program pembelajaran daring tersebut. Tujuan penelitian ini untuk mengevaluasi program pembelajaran daring dengan menggunakan model evaluasi program Context, Input, Process, and Product (CIPP) yang dirumuskan oleh Stufflebeam. Penelitian kuantitatif deskripstif ini menggunakan data primer yang dikumpulkan dari hasil kusioner dari dosen dan mahasiswa pada mata kuliah Evaluasi Program Pembelajaran sebagai sumber informan dan data sekunder yang diambil menggunakan dokumentasi berupa Rencana Pembelajaran Semester, materi perkuliahan, dan hasil tugas mata kuliah. Data yang terkumpul dianalisis menggunakan analisis statistik deskriptif. Hasil penelitian ini menunjukkan bahwa pelaksanaan pembelajaran daring di Pascasarjana Universitas Islam Negeri Alauddin Makassar, Program Studi Dirasah Islamiyah konsentrasi Pendidikan dan Keguruan mata kuliah Evaluasi Program Pembelajaran sudah berjalan dengan baik meskipun ada beberapa bagian yang masih perlu ditingkatkan seperti memaksimalkan penggunaan Learning Management Sistem (LMS), koordinasi yang jelas antara sesama dosen pengampu mata kuliah terkait Rencana Pembelajaran Semester (RPS) yang akan diterapkan selama satu semester dan pengkondisian yang ketat agar mahasiswa mengerjakan tugasnya secara bertanggungjawab (bebas plagiasi).

Kata Kunci: evaluasi program, pembelajaran daring, Context Input Process and Product (CIPP). 


\section{Introduction}

The implementation of online learning which was carried out in the past year during the Covid-19 pandemic has caused various impacts, both positive and negative impacts. The positive impacts are in the form of increasing the ability of students to find references on the internet, students can explore technology from an early age, doing several learning tasks at the same time, learning materials that can be saved or played back if they are not understood, and save on transportation expenses Impact The negative can be seen from the ineffectiveness of the teaching and learning system, dependence arises for students who cannot stay away from gadgets, spend a lot of money for internet quotas, not all children and parents can keep up with technological developments, and images or advertisements that appear to lead to pornography. ${ }^{1}$

There have been many studies conducted on online learning. The author can categorize the findings into three, namely (1) the positive impact of online learning; (2) the negative impact of online learning; (3) the learning model used during online learning. The results of the research on the positive impact of online learning were found in the form of (1) Development of independent character in students; ${ }^{2}$ (2) Trigger the acceleration of educational transformation; (3) Learners can access learning anywhere and anytime; ${ }^{3}$ and (4) Save on transportation expenses. ${ }^{4}$ The negative impacts of online learning that have been studied so far are: (1) Areas with minimal internet access experience barriers to learning and teaching activities; ${ }^{5}$ (2) Teachers are also less than optimal in providing learning materials; ; (3) Spending a lot of money for internet quotas, (4) Not all children and parents can keep up with technological developments, and (5) Some images or advertisements appear on social media that lead to pornography. ${ }^{7}$ The learning model used during online learning is the Project Based Learning learning model based on e-learning ${ }^{8,9}$. In addition, the Project Based Learning learning model is able to increase the creativity and motivation of students during online learning. The creativity that develops is not only seen in the skills of students in carrying out their projects, but also in the ability of students to utilize technology. ${ }^{10}$ The use of the ProjectBased Learning model with an online
${ }^{1}$ A. Risalah and Dkk, 'Dampak Pandemi Covid19 Terhadap Kegiatan Belajar Mengajar di MI/SD (Studi KBM Berbasis Daring Bagi Guru Dan Siswa)', JIEES, 1.1 (2020), 10-16.

${ }^{2}$ Rida Fironika Kusumadewi, Sari Yustiana, dan Khoirotun Nasihah, "Menumbuhkan Kemandirian Siswa Selama Pembelajaran Daring Sebagai Dampak Covid-19 di SD," JRPD (Jurnal Riset Pendidikan Dasar) 1, no. 1 (2020), h. 7-13.

${ }^{3}$ Ni Nyoman Serma Adi, Dewa Nyoman Oka, dan Ni Made Serma Wati, "Dampak Positif Dan Negatif Pembelajaran Jarak Jauh Di Masa Pandemi Covid-19," Jurnal Ilmiah Pendidikan dan Pembelajaran (JIPP) 5, no. 1 (2021).

4 Risalah dkk, "Dampak Pandemi Covid-19 Terhadap Kegiatan Belajar Mengajar Di MI/SD (Studi KBM Berbasis Daring Bagi Guru Dan Siswa)."
5 Adi, Oka dan Wati, "Dampak Positif Dan Negatif Pembelajaran Jarak Jauh Di Masa Pandemi Covid-19."

${ }^{6}$ Adi, Oka, and Wati.

7 Risalah dkk, "Dampak Pandemi Covid-19 Terhadap Kegiatan Belajar Mengajar Di MI/SD (Studi KBM Berbasis Daring Bagi Guru Dan Siswa).”

8 Chusnul Fauziah, Taufiqulloh, dan Hanung Sudibyo, "Implementasi Model Project Based Learning Pada Pembelajaran Jarak Jauh Berbasis E-Learning Selama Pandemi Covid-19," PSEJ 2 2, no. 2 (2017), h. 38-48.

${ }^{9}$ Indra Kurniawan Rezki, Joni Karnando, dan Elfi Tasrif, "Efektivitas E-Modul Berbasis Project Based Learning Selama Pembelajaran Jarak Jauh," Javit (Jurnal Vokasi Informatika) 1, no. 1 (2021), b. 1-4.

${ }^{10}$ Arum Ema Juwanti , "Project Based Learning (PjBL) Untuk PAI Selama Pembelajaran Daring," Jurnal Pendidikan Islam Al-Ilmi 3, no. 2 (2020), h. 72-82. 
assessment obtained better results compared to the use of conventional learning models. ${ }^{11}$

There are many studies on online learning, but current research on evaluating online learning programs in universities using the evaluation model of education policy programs is still very limited. Therefore, the presence of this study is expected to complement the shortcomings of previous studies. By looking at the characteristics of online learning, the authors assess the most appropriate program evaluation model used to assess online learning, namely Context, Input, Process, and Product (CIPP). The CIPP evaluation model developed by Stufflebeam at Columbus Ohio State University was chosen because this model has complete dimensions ranging from context, input, process, and product.

The CIPP evaluation model is one of the learning program evaluation models to evaluate Context, Input, Process, and Product. Stufflebeam stated that the CIPP evaluation model is a comprehensive evaluation model that has formative and summative functions. ${ }^{12}$ The CIPP evaluation model is an evaluation model that is considered the most comprehensive because this model emphasizes evaluation as a comprehensive process in the managerial system. ${ }^{13}$

Online learning, which is the focus of this research, is a learning program carried out at the Postgraduate Alauddin State Islamic University in Makassar, in the Dirasah Islamiyah Program with a concentration on Education and Teacher Training for the 2020/2021 Academic Year. During the Covid-19 pandemic, lectures and education administration are carried out online.

${ }^{11}$ Dwi Wahyu Nuryati, Siti Masitoh, dan Fajar Arianto, "Pengaruh Project Based Learning Terhadap Kreativitas Peserta Didik Di Masa Pandemi," Educate: Jurnal Teknologi Pendidikan 5, no. 2 (2020), h. 98-106.

12 Petrus Redy Patrus Jaya dan Felisitas Ndoet, "Penerapan Model Evaluasi CIPP Dalam Mengevaluasi
Based on the observations made by the researcher who is also one of the students in this Postgraduate program, it appears that several events are not in accordance with the ideals that arise during lectures, namely (1) lectures do not use the lantern application which is a special Learning Management System (LMS) application from campus, from 15 courses only 2 courses are used, and even then only for attendance purposes. Those two courses only lasted until the middle of the course because after the change of lecturers, they no longer used LMS Lentera; (2) There are sometimes students and lecturers who carry out the teaching and learning process in conditions where they carry out other activities, for example while in a vehicle; (3) There are also students who are late or in and out during lectures because the network is not stable, especially during bad weather conditions; (4) There are still many coursework assignments that are done by individuals and groups that have similarity above 50 percent, some even reach 90 percent; (5) The lecture system still uses the old tradition system, such as distributing meeting material to make papers, then students presenting papers, in the final session the lecturer explains. Then the MidSemester Examination (UTS) and Final Semester Examination (UAS) assignments are in the form of revisions of papers that have been made. In addition, there is also one course that requires a final assignment in the form of a handwritten resume.

The phenomenon that the researchers observed and experienced caused deep anxiety because the doctoral level based on the Indonesian National Qualifications Framework (KKNI) should have reached stage 9, namely

Program Layanan PAUD Holistik Integratif," PERNIK Jurnal PAUD 1, no. 1 (2018), h. 10-25.

${ }^{13}$ Hanung Sudibyo, Sugiyo, and Supriyo, "Model Evaluasi Layanan Informasi Bimbingan Dan Konseling Berbasis Context, Input, Process, Product (CIPP)," Jurnal Bimbingan Konseling 2, no. 1 (2013), h. 57-63. 
"Doing deepening and expansion of new science and technology through research, solving problems with a multi- or transdisciplinary approach". There are only two courses that display different learning methods, namely the Learning Technology course and Learning Program Evaluation because at the end of the course they want a product to be produced other than the paper.

Therefore, the researchers set the focus of the problem in this study covering the components that will be evaluated in the online learning program, namely (1) Context evaluation is an evaluation in the realm of decision planning; (2) Input evaluation is an evaluation in the realm of decision structuring;

(3) Process evaluation is an evaluation in the realm of implementing decisions; (4) Product evaluation is an evaluation in the realm of follow-up decisions.

Research problems that emphasize the effectiveness of each component in the CIPP evaluation model, namely: (1) In context evaluation, what should be done in online learning? (2) In the input evaluation, how is the online learning program carried out? (3) In the process evaluation, has online learning been carried out as planned or not? (4) In product evaluation, what are the results of online learning?

Many studies using the CIPP model program evaluation have been carried out. Based on existing research, the authors can

This study aims to evaluate online learning programs using the Context, Input, Process, and Product (CIPP) program evaluation model formulated by Stufflebeam. The results of the research are expected to be information material for policy/decisionmakers, especially regarding online learning at the Postgraduate Alauddin State Islamic University Makassar during the

The research was carried out at the Postgraduate Alauddin State Islamic University Makassar, Dirasah Islamiyah Study Program with a concentration on Education and Teacher conclude that the evaluation of the CIPP model program can be used in various forms of programs, ranging from education, health to community service. In addition, the results of the program evaluation shown using the CIPP method are considered more comprehensive because they evaluate starting from the context, inputs, processes, and outcomes of a program. The results of the program evaluation using the CIPP method produce policy recommendations that can be practical.

\section{Research Method}

This descriptive quantitative research uses an educational research approach because the main targets in this study are lecturers and students in the teaching and learning process. This study is an evaluation study of educational policy programs using the Context, Input, Process, and Product (CIPP) model formulated by Stufflebeam. The following is the design of the CIPP evaluation model, which can be seen in Figure 1 below:

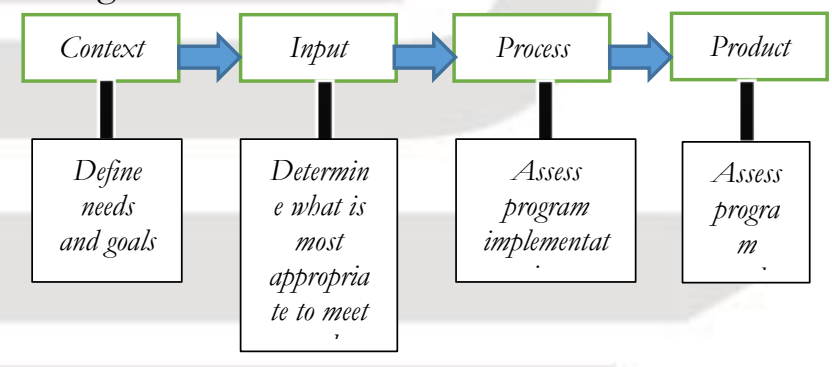

Figure 1. Component Flow of CIPP model

Informants in this study came from two directions, namely from lecturers and others from students. The lecturers in question are lecturers who are in charge of the Learning Program Evaluation courses, namely MMI and MII. Meanwhile, the selection of informants was based on a population sample technique, namely 9 people who were registered as students in the Learning Program Evaluation course.

The data used are primary data obtained from interviews with lecturers and students as 
informants and secondary data taken using documentation in the form of lesson plans, lecture materials in the form of PPT, and the results of course assignments. In obtaining the data in this study, there are core questions that must be answered in the research results, starting from context evaluation, input evaluation, process evaluation, and product evaluation.

The instruments used in this study are (1) Questionnaires compiled by researchers based on indicators of each component and aspect to be evaluated; (2) Observation guidelines compiled by researchers as a guide in conducting observations. As for the focus of observation are symptoms that cannot be measured using a questionnaire but can only be observed directly; (3) Interview guidelines prepared by researchers as a guide in conducting interviews. As for the focus of the interview is the deepening or expansion that can not be measured using a questionnaire but can only be expressed through a question and answer process; (4) Documents used by researchers to support research, for example, attendance documents, learning outcomes such as papers, etc.

In general, the instruments compiled refer to the guidelines for each component of the CIPP evaluation model. As shown in Table 1 below:

Table 1. CIPP Evaluation Model

\begin{tabular}{lll}
\hline $\begin{array}{l}\text { Evaluation } \\
\text { Aspect }\end{array}$ & Decision Type & $\begin{array}{l}\text { Types of questions } \\
\text { answered }\end{array}$ \\
\hline $\begin{array}{l}\text { Context } \\
\text { evaluation }\end{array}$ & Decision & Whanning should be \\
$\begin{array}{l}\text { Input } \\
\text { evaluation }\end{array}$ & Decision Setting & How do we do it? \\
\hline
\end{tabular}

\begin{tabular}{lll}
$\begin{array}{l}\text { Process } \\
\text { evaluation }\end{array}$ & $\begin{array}{l}\text { Implementing } \\
\text { Decisions }\end{array}$ & $\begin{array}{l}\text { Has it been carried } \\
\text { out according to } \\
\text { plan? Or not? }\end{array}$ \\
$\begin{array}{l}\text { Product } \\
\text { evaluation }\end{array}$ & $\begin{array}{l}\text { Follow-up } \\
\text { Decision }\end{array}$ & Has it been done? \\
\hline
\end{tabular}

Source: The CIPP approach to evaluation. ${ }^{14}$

The data collected were analyzed using descriptive statistical techniques by calculating the total score and percentage of each answer option.

\section{Results and Discussion}

The researcher explained the results of the study based on the steps for implementing the CIPP evaluation in accordance with the conditions that occurred in the online learning program for the Education Program Evaluation Course at the Postgraduate Alauddin State Islamic University Makassar, Dirasah Islamiyah Study Program in 2020/2021.

\section{Context Evaluation}

Context evaluation is an attempt to describe and detail the environment, unmet needs, populations and samples served, and the objectives of the program. ${ }^{15}$ Context evaluation is an attempt to describe and detail the environment, unmet needs, populations and samples served, and the objectives of the program. Context evaluation can help plan decisions, formulate program objectives and determine or identify needs to be achieved by a program. ${ }^{16}$

In evaluating this context, the fundamental question that must be answered is "what should be done?". Therefore, a needs analysis was carried out in order to get a detailed picture of the needs.

15 Mahmudi, 'CIPP: Suatu Model Evaluasi Program Pendidikan', Jurnal At-Ta'dib, 6.1 (2011).

16 Subar Junanto dan Nur Arini Asmaul Kusna, "Evaluasi Program Pendidikan Di PAUD Inklusi Dengan Model Context, Input, Process, and Product (CIPP)," INKLUSI: Journal of Disability Studies 5, no. 2 (2018), h. 179-194. 
Total Physical Response (TPR)

Conformity of Learning Objectives with Student Needs

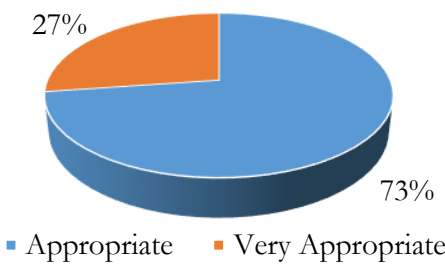

Figure 2. TPR Results Conformity of Learning Objectives with Student Needs

The results of Total Physical Response (TPR) based on Figure 2 above show that the learning objectives formulated in the syllabus are considered by most of the respondents to have been appropriate, $(73 \%)$ and some even judged to be very appropriate $(27 \%)$ with the needs of students. This can be seen from the RPS document or syllabus distributed by the lecturer which describes, in general, the learning objectives describe according to the needs of students as students of Education and Teacher Training (PK) concentration who will later conduct research based on educational settings.

The lecturer is the executor of the evaluation, and the target is the class and its students. Needs analysis is included when making lesson plans (RPS). The steps proposed by A. Badrujaman can be followed, as follows: (1) When the course schedule is out and the lecturer has been assigned the task of teaching, the lecturer must focus on achieving the learning objectives and then formulating the material; (2) The lecturer reviews the selected material and then matches it with the student's needs; (3) After the lecturer is sure that the selected material is in accordance with the needs of students, then the lecturer then determines the right strategy to deliver the material, including the delivery method or method, class management strategies and the selection of appropriate media.

Total Physical Response (TPR) Confirmity of Subject with Subject Achievement

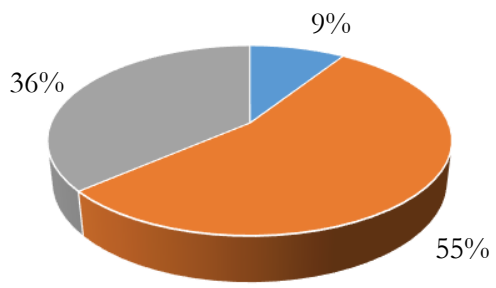

- Quite Appropriate - Appropriate

Figure 3. TPR Results Conformity of Subject Matter with Course Outcomes

Based on Figure 3 above, most of the subjects in the courses are considered to be appropriate $(55 \%)$, very appropriate $(36 \%)$, but there are also those who consider them to be quite appropriate $(9 \%)$ with course achievements. This can be seen from the RPS document or syllabus distributed by the lecturer which describes the subject matter in the course describing the achievement of the learning program evaluation course for students with the concentration of Education and Teacher Training (PK).

In order to respond to educational policies during the Covid-19 pandemic, learning patterns in the higher education environment are carried out online for theoretical and practical courses. Online learning is a form of learning innovation that involves information technology in learning. ${ }^{17}$ Therefore, lecturers continue to carry out online learning methods so that students can continue to attend lectures from their respective homes so that they continue to carry out social distancing.
${ }^{17}$ Ayu Wulandari dan Gusti Ngr Sastra Agustika, "Dramatik Pembelajaran Daring Pada Masa Pandemi
Covid-19," MIMBAR PGSD Undiksha 8, no. 3 (2020): 515-526. 
Total Physical Response (TPR)

Confirmity of Online Methods with

Student Conditions during the Covid19 Pandemic

$45,5 \%$

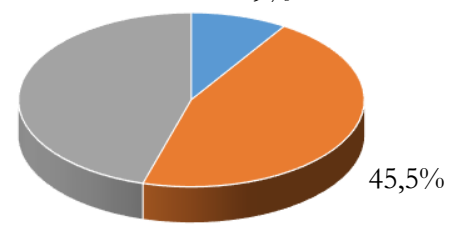

- Not Appropriate " Appropriate - Very Appropriate

Figure 4. Results of TPR Conformity of Online Methods with Student Conditions during the Covid-19 Pandemic

Based on the picture above, the lecture environment that uses the online method is considered appropriate $(45.5 \%)$ and even most of them rate it very appropriate $(45.5 \%)$, but there are also those who think that it is not appropriate $(9 \%)$ with the condition of students who are at school in the Covid-19 pandemic conditions. This can be seen from the online method used by lecturers which describes the condition of students during the Covid-19 pandemic, where there is a necessity to carry out the lecture process from home or online.

Total Physical Response (TPR) Accuracy of Online Learning Media (Zoom and LMS Lantern, WAG)

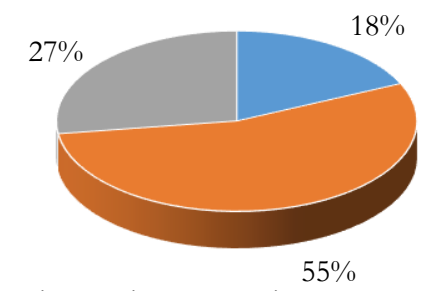

- Quite Precise " Precise " Very Precise

Figure 5. TPR Results on the Accuracy of Online Learning Media

Furthermore, regarding the online learning media used as shown in the figure above, it shows that most of them are rated precise $(55 \%)$ and very precise $(27 \%)$, but there are also those who rate quite precise $(18 \%)$. This is also supported by the statement given by the Education and Teacher Training (PK) concentration student that online lectures for learning evaluation courses using learning media such as Zoom and LMS Lentera and WAG assist students in delivering material during presentations and sending assignments to the lecturer concerned. and the message conveyed by the lecturer can be understood and understood well by students. In addition, learning from is also in accordance with their conditions as students and learning objectives are still achieved by continuing to practice social distancing. However, there are also students who state that the use of online learning media, especially Lentera LMS, has not been maximized, because Zoom is very limited in communicating, especially if the network is unstable.

\section{Input Evaluation}

Evaluation of inputs can help regulate decisions in providing information in determining the use of resources to achieve program objectives properly. Evaluation of input in learning that is meant is the initial ability of students and educational institutions that will support the program. Students here as recipients of lessons have different abilities, some are smart, less intelligent, and not smart. However, each student has their own talents in the intellectual, emotional, social and other fields that are special. ${ }^{18}$

An educator needs to know the character and specificity of each student so that educators are able to provide teaching and services appropriately. The things that must be known and understood by an educator from his students are as follows: (1) Intellectual ability;

18 Mahmudi, "CIPP: Suatu Model Evaluasi

Program Pendidikan,” Jurnal At-Ta'dib 6, no. 1 (2011). 
(2) Talent; (3) Physical conditions such as health, immunity and vulnerability. ${ }^{19}$

The results of Total Physical Response (TPR), based on Figure 6 below, show that most of the lecturers are considered to be tolerant $(55 \%)$ and some even think that the lecturers are very tolerant $(9 \%)$ and there are also those who think that the lecturers are quite tolerant $(27 \%)$, but there are also assessed that lecturers did not tolerant $(9 \%)$ physical or technical constraints experienced by their students. This can be seen from the way lecturers tolerate physical and technical constraints experienced by students of the Dirasah Islamiyah Study Program concentrating on Education and Teacher Training.

Total Physical Response (TPR) Lecturer's Tolerance to Students' (Physical or Technical) Constrains

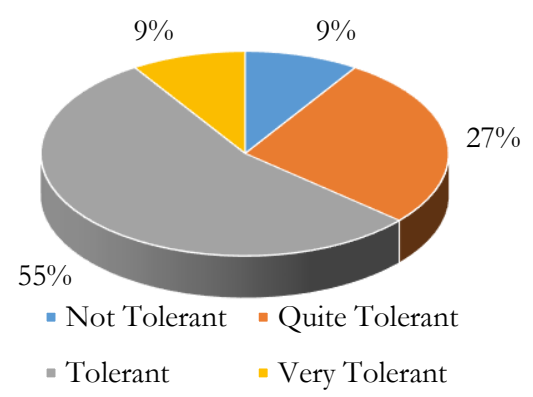

Figure 6. TPR Results of Lecturer Tolerance Against Obstacles (Physical or Technical) of

\section{Students}

The implementation of online learning during the Covid-19 pandemic requires teachers/lecturers to use learning media in order to convey material to students/students while still implementing social distancing. In addition, the government also encourages teachers or lecturers to use learning media so that learning can take place effectively. ${ }^{20}$ Therefore, teachers or lecturers must be skilled in choosing learning media so that the learning process can streamline the achievement of learning objectives in the teaching and learning process.

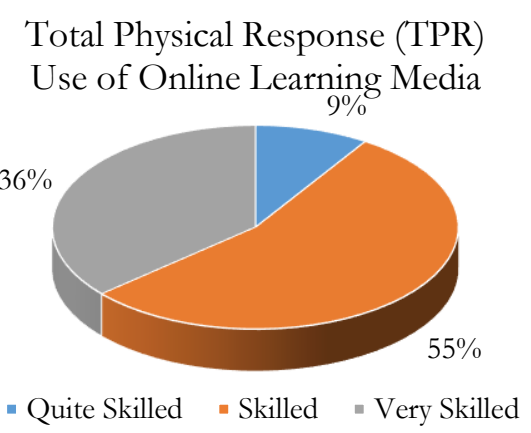

Figure 7. Results of TPR Using Online Learning Media

Based on Figure 7 above, most of the lecturers are considered skilled (55\%), very skilled (36\%), and some even rate quite skilled $(9 \%)$ in using learning media (Whatsapp Group, Zoom, LMS Lentera). This can be seen from the ability of the lecturers to describe the use of media (Whatsapp Group, Zoom, LMS Lentera) for learning skillfully during lectures, evaluating the learning program of the Dirasah Islamiyah Study Program with the concentration of Education and Teacher Training.

The trend of increasing the use of information and communication technology such as the use of the internet makes many schools and universities use the internet as a tool in learning. Many lessons are designed using online methods. The government through the ministry of education provides an Online Learning System (SPADA) grant which aims to equalize access to learning by opening online lectures that can be widely accessed by the public. ${ }^{21}$
19 Sukardi, Metodologi Penelitian Pendidikan: Kompetensi Dan Prakteknya (Jakarta: Bumi Aksara, 2007), h. 37.

\footnotetext{
20 Talizaro Tafonao, Peranan Media Pembelajaran Dalam Meningkatkan Minat Belajar
}

Mahasiswa: Jurnal Jurnal Komunikasi Pendidikan', Jurnal Jurnal Komunikasi Pendidikan, 2.2 (2018), 103-14.

${ }^{21}$ Syaiful Hamzah Nasution, 'Pentingnya Literasi Teknologi Bagi Mahasiswa Calon Guru Matematika', Jurnal Kajian Pembelajaran Matematika, 2.1 (2018), 14-18. 
Total Physical Response (TPR) Utilization of Information Technology in Online Learning

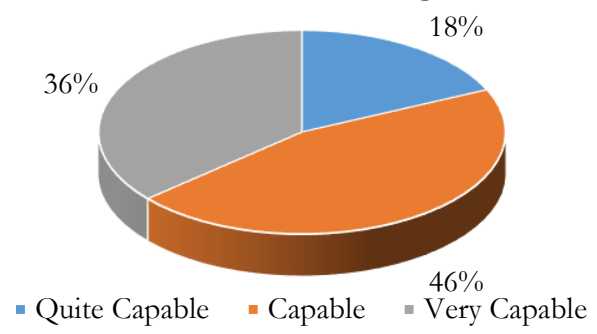

Figure 8. Results of TPR Utilization of Information Technology in Online Learning

Based on Figure 8 above, most of the students stated that they were able (46\%) even very capable $(36 \%)$, and some were quite capable $(18 \%)$ in utilizing information and communication technology to support online learning. This can be seen from the learning process which illustrates that students with the concentration of Education and Teacher Training (PK) are able to utilize information and communication technology to support online learning.

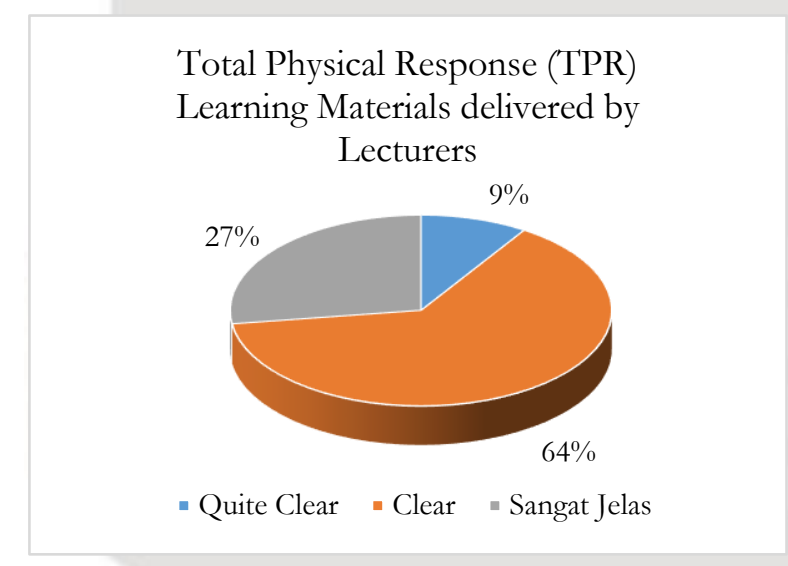

Figure 9. Results of TPR Learning Materials delivered by Lecturers

Furthermore, in Figure 9 above, most of the students considered that the learning material delivered by the lecturer was clear $(64 \%)$, very

22 Wirawan, Evaluasi: Teori, Model, Standar, Aplikasi, Dan Profesi (Jakarta: Rajawali Pers, 2012), h. 92.

23 Subar Junanto dan Nur Arini Asmaul Kusna, "Evaluasi Program Pendidikan Di PAUD Inklusi Dengan Model Context, Input, Process, and Product (CIPP)," clear $(27 \%)$ and some even considered it quite clear $(9 \%)$ so that it could be understood. This can be seen from most of the students describing the learning materials delivered by lecturers in the evaluation courses of educational programs that are clearly described so that they are easy to understand.

\section{Process Evaluation}

Process evaluation is directed at how far the activities carried out in the program have been carried out according to the plan. ${ }^{22}$ Process evaluation includes the collection of research data that has been determined and applied in program implementation practices. ${ }^{23}$ At this stage it is associated with program implementation. Stufflebeam in Suharsimi provides the questions asked in the evaluation of this process are as follows: "(1) Is the implementation of the program according to schedule?; (2) Will the staff involved in the program implementation process be able to handle activities during the program and if it is likely to continue?; (3) Are the facilities and infrastructure provided used optimally?; (4) What are the obstacles encountered during the implementation of the program and what are the possibilities if the program is continued?" 24

These questions state that the object of process evaluation is an assessment of the learning process in class. Then the data sources are lecturers and students. Giving an assessment of the learning process to see the effectiveness of learning and changes in student behavior.

To assess the learning process, it is necessary to look at the components that make up it. The components referred to include (1) instructional objectives; (2) Teaching materials; (3) Students; (4) Educators; (5) Learning tools

INKLUSI: Journal of Disability Studies 5, no. 2 (2018), h. 179-194.

24 Suharsimi Arikunto dan Cepi Safruddin Abdul Jabar, Evaluasi Program Pendidikan: Pedoman Teoritis Bagi Mahasiswa Dan Praktisi Pendidikan, Ed 2, Cet. IV, (Jakarta: Bumi Aksara, 2010), h. 45. 
and resources; and (6) Assessment. Each component relates the aspects in it and these components are interrelated with each other. Lecturers must assess not only aspects of the students, but also the relationship between students and lecturers, teaching materials, and learning objectives. That assessment was carried out to measure success in achieving the goals that have been set. ${ }^{25}$

The results of Total Physical Response (TPR), based on Figure 10 below, show that the learning process that took place was mostly judged to be appropriate (36\%), very suitable $(46 \%)$, and some even considered quite appropriate $(9 \%)$ but some who judged not in accordance $(9 \%)$ with a predetermined schedule. This can be seen from the implementation of the learning process for the evaluation course of the learning program taking place in accordance with the predetermined lecture schedule.

Total Physical Response (TPR) Utilization of Facilities and Infrastructure

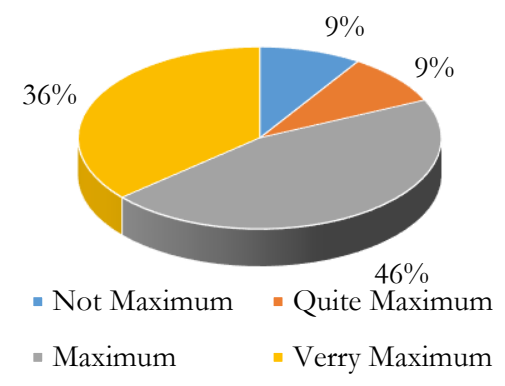

Figure 10. Results of TPR Implementation of the Learning Process

Then, if viewed from its suitability with the planning contained in the syllabus, it shows that the implementation of learning is mostly considered appropriate $(36.5 \%)$ and even very appropriate $(27 \%)$, and many consider it quite appropriate $(36.5 \%)$ with the planning contained in the syllabus. in the syllabus. This can be seen from the planning contained in the

25 Subar Junanto dan Nur Aini Asmaul Kusna, "Evaluasi Program Pembelajaran PAUD Inklusi dengan Model Context, Input, Process, and Product (CIPP)", syllabus described in accordance with the implementation of student learning with the concentration of Education and Teacher Training (PK). Furthermore, the learning process was assessed as appropriate $(27 \%)$ and even most of them considered it very suitable (64\%), but some considered it quite appropriate $(9 \%)$ taking place actively in a participatory manner. This can be seen from the learning process, the evaluation of the learning program depicts an active participatory process.

When viewed in terms of facilities and infrastructure, in Figure 11 below, most of the utilization of facilities and infrastructure is rated maximum (46\%) and very maximum (36\%) and some even rate it as quite maximum (9\%), but there are also those who rate it as not. maximum $(9 \%)$ during learning. This can be seen from the facilities and infrastructure for the concentration of Education and Teacher Training (PK) which illustrates that it can be utilized optimally during the learning process.

Total Physical Response (TPR) Smooth Learning Process

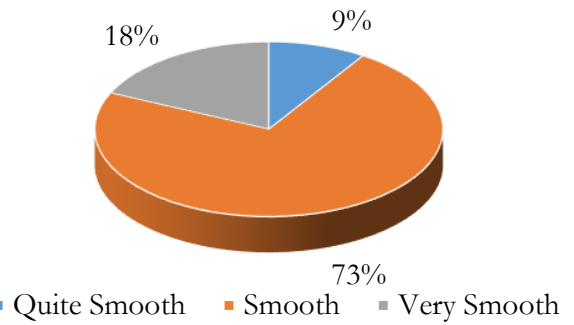

Figure 1.

Results of TPR Utilization of Facilities and Infrastructure
INKLUSI: Journal of Disability Studies V, no. 2 (2018), h. 179-194. 
When viewed from the learning process, Figure 12 below shows that most of the learning process was considered smooth $(73 \%)$ and some even rated it very smooth (18\%), and some rated it quite smooth $(9 \%)$. Furthermore, during the learning process the most common obstacles experienced were network constraints, some stated that the lecturer's presentation of the sub-materials still needed to be explained in more detail, the absorption ability of students varied, lecturers sometimes forgot the agreed time, and there were different syllabuses that were followed. However, there are also those who stated that they did not have obstacles during the learning process.

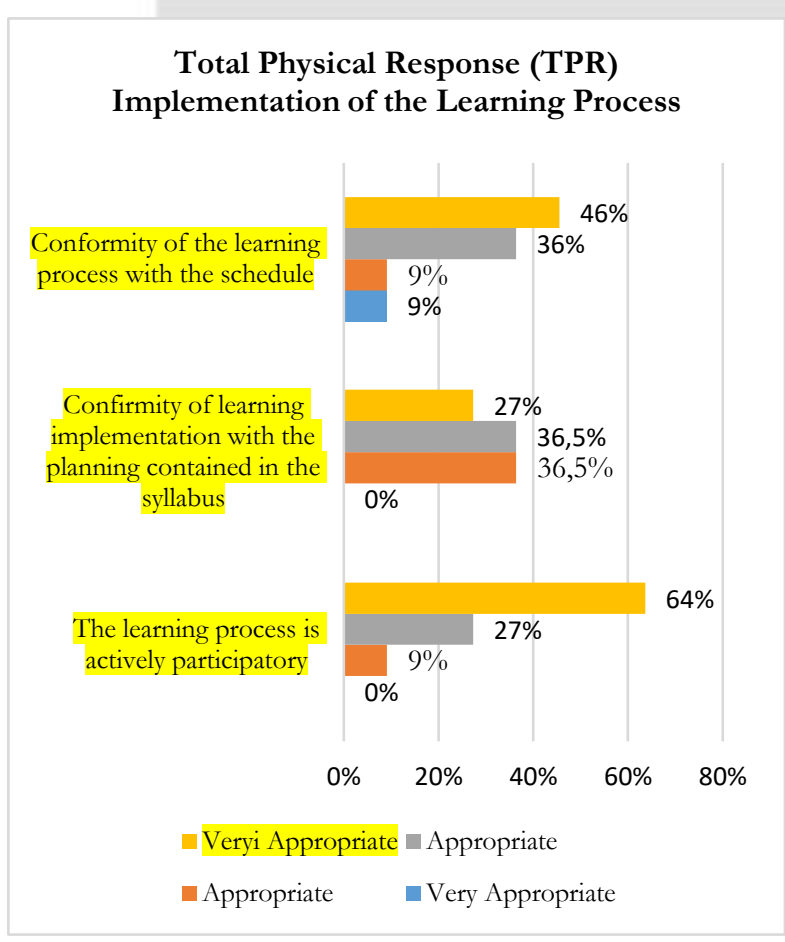

Figure 12. TPR Results for Smooth Learning Process
Learning in the network (online) is a teaching and learning process that utilizes electronic devices, especially the internet in the process of implementing learning. ${ }^{26}$ The term online learning was originally only used to describe a learning system that utilizes computer-based internet technology. ${ }^{27}$ However, today its understanding is increasingly widespread by using Android.

Online learning relies on a cellphone or laptop, credit, quota, and a stable and good internet network. In addition, there are generally inhibiting factors for online learning, namely: (1) Educators need time to adapt to distance learning; (2) Not all students have mobile phones; (3) There is a sense of laziness in students when doing assignments, even though it is supported by facilities that support learning; and (4) there are still many parents who work so they cannot fully guide students in learning. ${ }^{28}$

\section{Product Evaluation}

Product evaluation in learning is the learning outcomes of students in this study, namely the learning outcomes of students. The basic question that must be answered in this product evaluation section is "Has the learning program been implemented? What are the results like?" According to Benjamin, S. Bloom ${ }^{29}$ in Abidin, learning outcomes are classified into three domains, namely cognitive, affective, and psychomotor. Product evaluation is an assessment carried out to measure success in achieving the goals that have been set. ${ }^{30}$
${ }^{26}$ Henri Aditia Rigianti, "Kendala Pembelajaran Daring Guru Sekolah Dasar Di Kabupaten Banjarnegara," Elementary School 7, no. 2 (2020), h. 297-302.

27 Eko Kuntarto, "Keefektifan Model Pembelajaran Daring Dalam Perkuliahan Bahasa Indonesia Di Perguruan Tinggi," Journal Indonesian Language Education and Literatur 3, no. 1 (2017), h. 99-110.

${ }^{28}$ Hilna Putria, Luthfi Hamdani Maula, dan Din Azwar Uswatun, “Analisis Proses Pembelajaran Dalam Jaringan (DARING) Masa Pandemi COVID-19 Pada
Guru Sekolah Dasar," Jurnal Basicedu 4, no. 4 (2020), h. 869-870.

${ }^{29}$ M.Z. Abidin, 'Taksonomi Bloom, Konsep Dan Iplikisinya Bagi Pendidikan Matematika', Jurnal Masbied, 03.20 (2010).

30 Subar Junanto dan Nur Aini Asmaul Kusna, "Evaluasi Program Pembelajaran PAUD Inklusi dengan Model Context, Input, Process, and Product (CIPP)", INKLUSI: Journal of Disability Studies V, no. 2 (2018), h. 179-194. 
Total Physical Response (TPR)

Student Knowledge About Program

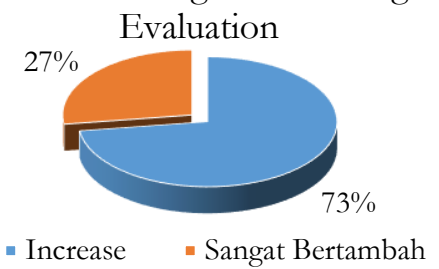

Figure 13. TPR Results of Student Knowledge About Program Evaluation

The results of Total Physical Response (TPR) based on Figure 13 above show that most of the students' knowledge of program evaluation was assessed to increase $(72 \%)$ and some even assessed that it was greatly increased $(27 \%)$ after carrying out learning. It can be seen from the knowledge of the concentration of Education and Teacher Training (PK) students about program evaluation that it describes the increase after the learning process.

Furthermore, when viewed from the student's ability to implement program evaluation, Figure 14 below shows that students are considered capable (64\%) and some are considered quite capable $(27 \%)$, but some assess are not able $(9 \%)$ to apply for an evaluation research program after undergoing the learning process. It can be seen from the concentration of Education and Teacher Training (PK) students who describe being able to apply program evaluation research after undergoing the learning process.

Total Physical Response Student Ability to Apply Program Evaluation Research

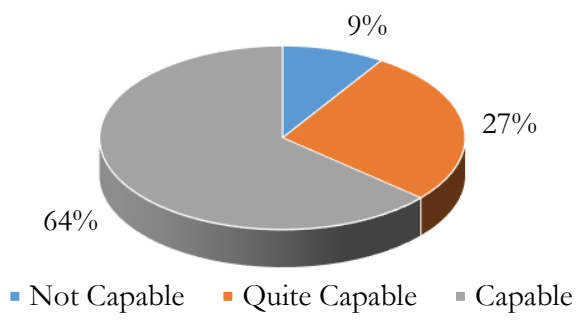

Figure 14. TPR Results of Students' Ability to Apply Program Evaluation Research
Based on the findings, it can be described the findings of each stage of the evaluation of online learning programs using the CIPP model. In terms of context evaluation, it can be stated that: (1) learning objectives have been formulated in the course syllabus according to student needs, (2) the sub-topics in the program evaluation course have been in accordance with the course achievements, (3) the lecture environment is conducive to learning. using the online method is following the conditions of students who are in a Covid-19 pandemic condition, and (4) the online learning media (Zoom and Lentera Learning Management System) used is appropriate.

In terms of input evaluation, it can be stated that: (1) lecturers tolerate physical or technical constraints experienced by their students, (2) lecturers are able to use learning media skillfully, (3) students are able to utilize information and communication technology to support online learning, and (4) the learning material delivered by the lecturer is clear enough so that it can be understood.

In terms of process evaluation, it can be stated that: (1) the implementation of learning according to the schedule, (2) the implementation of learning according to the planning contained in the syllabus, (3) the learning process takes place in an actively participatory manner, (5) facilities and infrastructure can be utilized optimally during learning, and (6) the learning process runs smoothly.

In terms of product evaluation, it can be stated that: (1) students' knowledge of program evaluation increases after learning is carried out, and (2) students are able to apply program evaluation research after undergoing the learning process.

The presence of the results of this research can be used as one of the information materials for policy/decision-makers especially regarding online learning at the Postgraduate Alauddin State Islamic University Makassar 
during the implementation of the new normal post-covid-19 pandemic. This is supported because program evaluation is indeed an activity or series of activities to find out how successful a program or planned activity is. ${ }^{31}$ Stufflebeam who is an evaluation expert said that program evaluation is a process of searching, describing, and providing information that is very useful for decision making in determining alternative decisions. ${ }^{32}$

There are various suggestions from the respondents that can be used as recommendations so that online learning can run optimally, namely:

For the Government or educational institutions: (a) Providing network facilities or quotas for lecturers and students so that internet access is smooth; (b) Create a program/matriculation to improve writing skills of scientific/IT/foreign languages for new students before attending lectures; (c) Providing training on learning applications from lecturers and students; (d) Making strict regulations against violations of academic ethics on student assignments which are allegedly original from their thoughts.

Students: (a) Improve independent study skills (read more and more quality references); (b) Improve skills in using applications that help in carrying out tasks; (c) Be responsible for the work that has been made by making original works free of plagiarism; (d) Improving self-regulated learning so that lectures are still maximized without being

31 Suharsimi Arikunto, Dasar-Dasar Evaluasi Pendidikan (Jakarta: Bumi Aksara, 2005), h. 291.

32 Suharsimi Arikunto dan Cepi Safruddin Abdul Jabar, Evaluasi Program Pendidikan: Pedoman Teoritis Bagi Mahasiswa Dan Praktisi Pendidikan, Ed 2, Cet. IV, (Jakarta: Bumi Aksara, 2010), h. 30.

${ }^{33}$ Wicka Yunita Dwi Utami, Martini Jamaris, and Sri Martini Meilanie, "Evaluasi Program Pengelolaan Lembaga PAUD Di Kabupaten Serang," Jurnal Obsesi: Jurnal Pendidikan Anak Usia Dini 4, no. 1 (2020), h. 67. disturbed by additional tasks outside of lectures.

Lecturers: (a) Understand the development of evaluation/policy research concepts; (b) Expanding more creative learning models; (c) Maximize the use of lanterns for all lectures; (d) Synergy between lecturers with one another (team teaching); (e) Consistent with the syllabus and course achievements; (f) Consistently giving assignment instructions so that students are not confused; (g) Provide tolerance regarding unstable network.

Findings that imply recommendations in this study were also found from the results of various program evaluation studies using CIPP. As the results of research by Wicka Yunita Dwi Utami, Martini Jamaris, Sri Martini Meilanie ${ }^{33}$ show that there is a need for educators and education personnel to improve their competence and the need for supervisors or institutional builders to increase awareness in supervising and fostering institutions in order to improve the quality of education.

The results of the research by Iwan Supriyantoko, Akbar Jaya, Vidyatama Kurnia, and Putri Ghanim Septia Habib ${ }^{34}$ imply the need for a Teaching Factory because teachers who teach must have appropriate skills in their fields so that they can foster an entrepreneurial spirit in students and prepare them to become workers and continue their studies.

Narges Neyazi's research, Mohammad $\mathrm{Arab}^{35}$ found out how the quality level of

34 Iwan Supriyantoko, dkk, "Evaluasi Implementasi Kebijakan Teaching Factory Dengan Model Evaluasi CIPP Di SMK Negeri DKI Jakarta," JVTE: Journal of Vocational and Technical Education 2, no. 2 (2020), h. 1-10.

35 Narges Neyazi, Mohammad Arab, "Evaluation of selected faculties at tehran university of medical sciences using CIPP model in students and graduates point of view", Evaluation and Program Planning, 59, 2016, h. 88. 
courses in the undergraduate program was based on the perspectives of students and alumni and determined their weak points. The results showed that there were undesirable situations or conditions of context, process and product components and undesirable situations for the input components except for the factor "student interest and understanding of the field and the job market", which had a relatively desirable situation. In the end, the researcher recommends several things to improve the goals and mission of the program, allocate budget, curriculum and provide a communication system with alumni.

The Research of E. Akdogdu and S Usun ${ }^{36}$ implemented for the improvement of teaching in the classroom. Even a different study conducted by C. Balikci et al ${ }^{37}$ found that program evaluation using CIPP implemented curriculum changes in the education unit.

These various evaluation studies produce benefits that can be implemented in institutions as also found in this study because basically the results of evaluation research are intended to be used as consideration for making decisions. Especially if you use the right evaluation research model, such as CIPP.

The CIPP model has advantages, including: (1) It is more comprehensive than other models. Because the object of evaluation is not only on results but also includes context, input, process, and results; (2) Having a holistic approach in evaluation because it aims to provide a very detailed and broad picture of the project, starting from its context to the time of the implementation process; (3) Has the potential to work in the area of formative and summative evaluation, so it is equally good at

36 E. Akdogdu and S Usun, "Evaluation of Classroom Teaching Undergraduate Program in Accordance with the Pre-Service Teachers' Opinions Using Context, Input, Process, Product (CIPP) Model," Elementary Education Online 16, no. 2 (2017), h. 826.

37 C. Balikci dkk, "The Evaluation of Primary School Third Grade Science Curriculum as Based on helping make improvements during the program as well as providing final information. ${ }^{38}$

\section{Conclusion}

The conclusion in this study is that the implementation of online learning at the Postgraduate Alauddin State Islamic University in Makassar, the Dirasah Islamiyah Study Program for the Learning Program Evaluation course has been going well although there are still some things that are not optimal.

The form of recommendations resulting from the findings of this study is to the government to maximize the availability of facilities and infrastructure in online learning, and the university to prepare strict regulations against plagiarism that has a high chance of occurring during online learning. Furthermore, for students to be able to increase their personal capacity as dignified learning beings. Lastly, for lecturers to improve the competence of professional educators, especially in mastering teaching using information technology. For the next researcher to complete in-depth interviews at each stage at CIPP to make clear findings that were not revealed using a questionnaire.

\section{References}

Book

Arikunto, Suharsimi, Dasar-Dasar Evaluasi Pendidikan (Jakarta: Bumi Aksara, 2005)

\section{Journal}

Abidin, M.Z., 'Taksonomi Bloom, Konsep Dan Iplikisinya Bagi Pendidikan Matematika', Jurnal Masbied, 03.20 (2010)

Context-Input-Process-Product (CIPP) Model," Milli Egitim 50, no. 229 (2021), h. 523.

38 E. P. Widiyoko, Evaluasi Program Pembelajaran: Panduan Praktis Pendidik Dan Calon Pendidik (Yogyakarta: Pustaka Pelajar, 2009), h. 45. 
Adi, Ni Nyoman Serma, Dewa Nyoman Oka, and Ni Made Serma Wati, 'Dampak Positif Dan Negatif Pembelajaran Jarak Jauh Di Masa Pandemi Covid-19', Jurnal Ilmiah Pendidikan Dan Pembelajaran (IIPP), 5.1 (2021)

Akdogdu, E., and S Usun, 'Evaluation of Classroom Teaching Undergraduate Program in Accordance with the PreService Teachers' Opinions Using Context, Input, Process, Product (CIPP) Model', Elementary Education Online, 16.2 (2017), 826

Arikunto, Suharsimi, and Cepi Safruddin Abdul Jabar, Evaluasi Program Pendidikan: Pedoman Teoritis Bagi Mahasiswa Dan Praktisi Pendidikan, Ed 2, Cet. (Jakarta: Bumi Aksara, 2010)

Balikci, C., C. Tuysuz, D. I. Ekicoz, and A. Tasdere, 'The Evaluation of Primary School Third Grade Science Curriculum as Based on Context-Input-ProcessProduct (CIPP) Model', Milli Egitim, 50.229 (2021), 523

Fauziah, Chusnul, Taufiqulloh, and Hanung Sudibyo, 'Implementasi Model Project Based Learning Pada Pembelajaran Jarak Jauh Berbasis E-Learning Selama Pandemi Covid-19', PSEJ 2, 2.2 (2017), 38-48

Jaya, Petrus Redy Patrus, and Felisitas Ndoet, 'Penerapan Model Evaluasi CIPP Dalam Mengevaluasi Program Layanan PAUD Holistik Integratif, PERNIK Jurnal PAUD, 1.1 (2018), 10-25

Junanto, Subar, and Nur Arini Asmaul Kusna, 'Evaluasi Program Pendidikan Di PAUD Inklusi Dengan Model Context, Input, Process, and Product (CIPP)', INKLUSI: Journal of Disability Studies, 5.2 (2018), 179-94

$<$ https://doi.org/doi.org/10.14421/ijds $.050202>$

Juwanti, Arum Ema, Unik Hanifah Salsabila, Cikal Jiwai Putri, Alma Livia Dewi Nurany, and Fitri Nur Cholifah, 'Project Based Learning (PjBL) Untuk PAI Selama Pembelajaran Daring', Jurnal Pendidikan Islam Al-Ilmi, 3.2 (2020), 72-82 $<$ https://doi.org/10.32529/alilmi.v3i2.752>
Kuntarto, Eko, 'Keefektifan Model Pembelajaran Daring Dalam Perkuliahan Bahasa Indonesia Di Perguruan Tinggi', Journal Indonesian Language Education and Literatur, 3.1 (2017), 99-110

Kusumadewi, Rida Fironika, Sari Yustiana, and Khoirotun Nasihah, 'Menumbuhkan Kemandirian Siswa Selama Pembelajaran Daring Sebagai Dampak Covid-19 Di SD', JRPD (Jurnal Riset Pendidikan Dasar), 1.1 (2020), 7-13

Mahmudi, 'CIPP: Suatu Model Evaluasi Program Pendidikan', Jurnal At-Ta'dib, 6.1 (2011)

Nasution, Syaiful Hamzah, 'Pentingnya Literasi Teknologi Bagi Mahasiswa Calon Guru Matematika', Jurnal Kajian Pembelajaran Matematika, 2.1 (2018), 14-18

Nuryati, Dwi Wahyu, Siti Masitoh, and Fajar Arianto, 'Pengaruh Project Based Learning Terhadap Kreativitas Peserta Didik Di Masa Pandemi', Educate : Jurnal Teknologi Pendidikan, 5.2 (2020), 98-106 $<$ https://doi.org/dx.doi.org/10.32832/ educate.v5i2.3375>

Pradinata, Andry, 'Evaluasi Program Pendidikan Model CIPP', Andripradinata.Blogspot.Com, 2012

Putria, Hilna, Luthfi Hamdani Maula, and Din Azwar Uswatun, 'Analisis Proses Pembelajaran Dalam Jaringan (DARING) Masa Pandemi COVID-19 Pada Guru Sekolah Dasar', Jurnal Basicedu, 4.4 (2020), 869-70

Rezki, Indra Kurniawan, Joni Karnando, and Elfi Tasrif, 'Efektivitas E-Modul Berbasis Project Based Learning Selama Pembelajaran Jarak Jauh', JAVIT (Jurnal Vokasi Informatika), 1.1 (2021), 1-4

Rigianti, Henri Aditia, 'Kendala Pembelajaran Daring Guru Sekolah Dasar Di Kabupaten Banjarnegara', Elementary School, 7.2 (2020), 297-302

Risalah, A., and Dkk, 'Dampak Pandemi Covid-19 Terhadap Kegiatan Belajar Mengajar Di MI/SD (Studi KBM Berbasis Daring Bagi Guru Dan Siswa)', JIEES, 1.1 (2020), 10-16

Sudibyo, Hanung, Sugiyo, and Supriyo, 'Model Evaluasi Layanan Informasi Bimbingan Dan Konseling Berbasis Context, Input, 
Process, Product (CIPP)', Jurnal Bimbingan Konseling, 2.1 (2013), 57-63

Sukardi, Metodologi Penelitian Pendidikan: Kompetensi Dan Prakteknya (Jakarta: Bumi Aksara, 2007)

Supriyantoko, Iwan, and Dkk, 'Evaluasi Implementasi Kebijakan Teaching Factory Dengan Model Evaluasi CIPP Di SMK Negeri DKI Jakarta', JVTE: Journal of Vocational and Technical Education, 2.2 (2020), 1-10

Tafonao, Talizaro, 'Peranan Media Pembelajaran Dalam Meningkatkan Minat Belajar Mahasiswa: Jurnal Jurnal Komunikasi Pendidikan', Jurnal Jurnal Komunikasi Pendidikan, 2.2 (2018), 103-14
Utami, Wicka Yunita Dwi, Martini Jamaris, and Sri Martini Meilanie, 'Evaluasi Program Pengelolaan Lembaga PAUD Di Kabupaten Serang', Jurnal Obsesi: Jurnal Pendidikan Anak Usia Dini, 4.1 (2020), 67

Widiyoko, E. P., Evaluasi Program Pembelajaran: Panduan Praktis Pendidik Dan Calon Pendidik (Yogyakarta: Pustaka Pelajar, 2009)

Wirawan, Evaluasi: Teori, Model, Standar, Aplikasi, Dan Profesi (Jakarta: Rajawali Pers, 2012)

Wulandari, Ayu, and Gusti Ngr Sastra Agustika, 'Dramatik Pembelajaran Daring Pada Masa Pandemi Covid-19', MIMBAR PGSD Undiksha, 8.3 (2020), 515-26 